\title{
Site-directed mutagenesis of the hydrogenase signal peptide consensus box prevents export of a $\beta$-lactamase fusion protein
}

\author{
VINCENT NivièRe, $†$ SUI-LAM WoNG and GeRrit VoORDOUW* \\ Division of Biochemistry, Department of Biological Sciences, The University of Calgary, Alberta, Canada)T2N 1N4
}

(Received 27 April 1992; revised 30 June 1992; accepted 6 July 1992)

\begin{abstract}
A secretion vector, pVN1, expressing the [NiFe] hydrogenase signal peptide of Desulfovibrio vulgaris Hildenborough fused to $\beta$-lactamase from Escherichia coli was constructed in order to study the unusual characteristics of hydrogenase signal peptides, which share a strictly conserved sequence, the consensus box: $R-R-$ $X-F-X-K$. Although the hydrogenase signal peptide- $\beta$-lactamase fusion protein was processed much more slowly than the fusion of $\beta$-lactamase with its own signal peptide, the system mimicked several features expected for hydrogenase biosynthesis in $E$. coli, including increased export under anaerobic conditions. Site-directed mutagenesis of $\mathbf{R}(-\mathbf{2 8})$, the first arginine residue of the consensus box, to a glutamate completely inhibited export and processing of the fusion protein. The same mutation of $R(-33)$, located outside the consensus box, had almost no effect. The data indicate a specific role for the consensus box sequence in the export mechanism for hydrogenase.
\end{abstract}

\section{Introduction}

Proteins to be exported from the cell cytoplasm are synthesized as precursors containing an $\mathrm{NH}_{2}$-terminal extension of 15-30 amino acid residues. This extension, the signal peptide, is the main determinant for protein localization to the periplasm. Following translocation across the cytoplasmic membrane, this signal peptide is cleaved by a specific membrane-bound signal peptidase, to yield the mature protein. Sequence comparison of signal peptides has shown that there is no strict sequence conservation among these peptides (Gierasch, 1989; Von Heijne, 1985; Watson, 1984). However, three different domains can be assigned to a classical signal peptide. These are: (i) an $\mathbf{N H}_{2}$-terminal positively charged region, (ii) a central hydrophobic region of 8-10 amino acid residues, and (iii) a COOH-terminal segment which

\footnotetext{
- Author for correspondence. Tel. 403-220-6388; fax 403 289-9311; email: voordouw@acs.ucalgary.ca.

$\dagger$ Present address: Laboratoire du Pr. Fontecave, Universite J. Fourier, 301 Rue de la Chimie, Domaine Universitaire St Martin d'Heres, 38041 Grenoble Cedex, France.
}

Abbreviations: PADAC, 7-(thienyl-2-acetamido)-3-[2-(4- $N, N$ dimethylaminophenylazo)pyridinium methyl]-3-cephem-4 carboxylic acid.

The nucleotide sequence data reported in this paper have been submitted to GenBank and have been assigned the accession number M97299. includes the signal peptidase cleavage site (Schatz and Beckwith, 1990).

In the last seven years, the cloning and sequencing of structural genes for hydrogenases has revealed the presence of unusual signal peptides (Fig. 1). Hydrogenase, a bacterial enzyme, which catalyses the reversible oxidation of molecular hydrogen, is often located in the periplasmic space (Nivière et al., 1991; Van der Westen et al., 1978) or found associated with the membrane (Rhode et al., 1990). Periplasmic hydrogenases consist of a large $(45-65 \mathrm{kDa})$ and a small $(9-30 \mathrm{kDa})$ subunit, encoded by a single operon. These enzymes always contain iron-sulphur clusters as prosthetic groups, and some also contain nickel. On the basis of the prosthetic group at the active site of the enzyme, three classes of hydrogenases have been described: the [Fe], [NiFe] and [NiFeSe] hydrogenases (Fauque et al., 1988). The [NiFe] and [NiFeSe] hydrogenases have homologous primary sequences. However, the [Fe] hydrogenases do not share primary sequence homology with these two nickelcontaining enzymes (Voordouw, 1990).

An $\mathrm{NH}_{2}$-terminal signal peptide is only present in the small subunit (pro- $\beta$ ) of the three classes of hydrogenases (Fig. 1). The large $(\alpha)$ subunit does not have an $\mathbf{N H}_{2}-$ terminal signal peptide and no evidence for an internal signal sequence has so far been obtained. The pro- $\beta$ signal peptides are exceptionally long (32-50 residues) and have a complex $\mathrm{NH}_{2}$-terminal domain with positive 


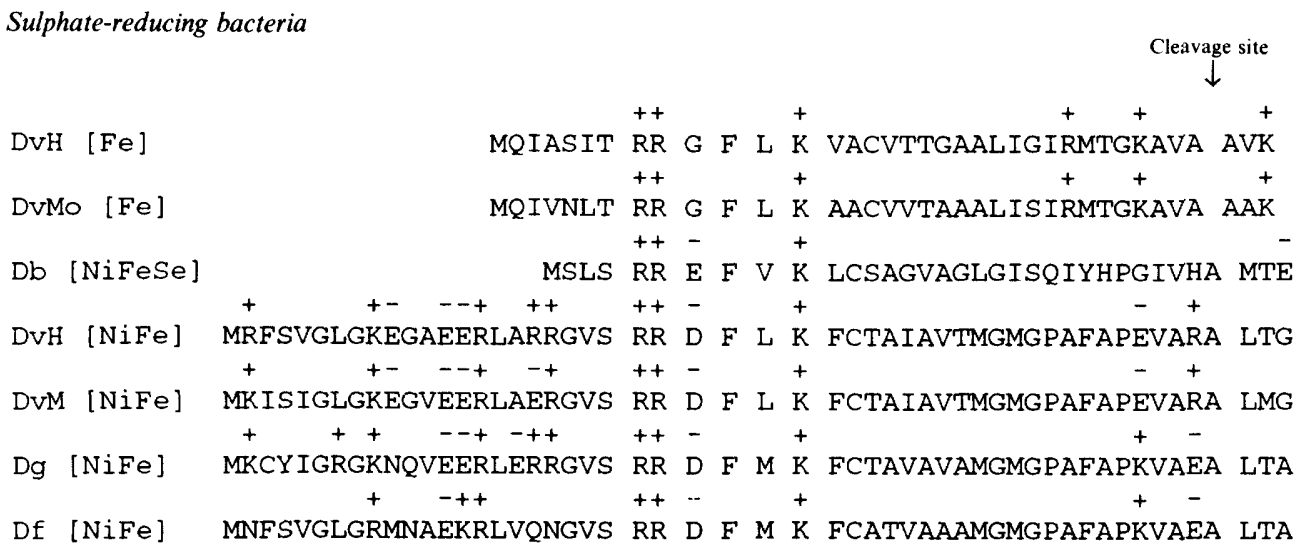

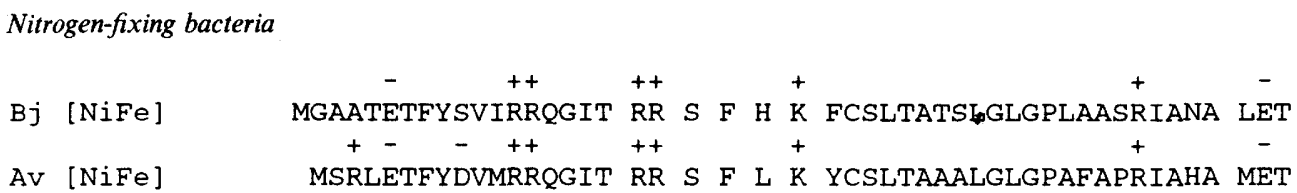

Photosynthetic bacteria

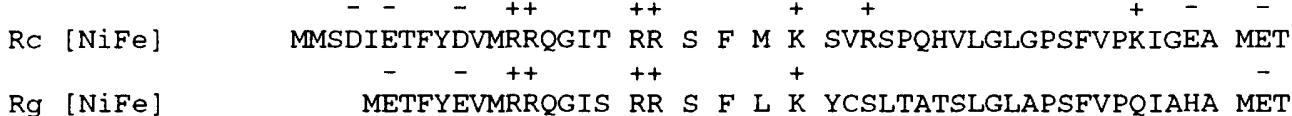

Enterobacteria

Ec $[\mathrm{NiFe}]$

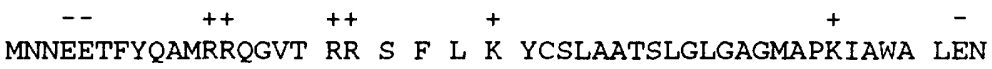

$$
\begin{aligned}
& \text { Consensus box : } \begin{array}{lll}
++ & & + \\
\text { FR } & \text { K }
\end{array}
\end{aligned}
$$

Fig. 1. Signal peptide sequences determined for small subunits of $[\mathrm{Fe}],[\mathrm{NiFe}]$ and $[\mathrm{NiFeSe}]$ hydrogenases from different microorganisms. The sequences have been aligned relative to the consensus sequence RRXFXK. Positively (+;R, K) and negatively (-; E, D) charged amino acid residues are indicated. The following are the full names of the micro-organisms and references to the sequences: DvH [Fe] is D. vulgaris Hildenborough (Voordouw \& Brenner, 1985); DvMo [Fe] is D. vulgaris oxamicus Monticello (Voordouw et al., $1989 b$ ); $\mathrm{Db}$ [NiFeSe] is $D$. baculatus (Voordouw et al., 1989a); $\mathrm{DvH}[\mathrm{NiFe}]$ is $D$. vulgaris Hildenborough (this study); $\mathrm{DvM}[\mathrm{NiFe}]$ is $D$. vulgaris Miyazaki (Deckers et al., 1990); $\mathrm{Dg}$ [NiFe] is D. gigas (Voordouw et al., 1989a); Df [NiFe] is D. fructosovorans (Rousset et al., 1990); $\mathrm{Bj}$ [NiFe] is Bradyrhizobium japonicum (Sayavedra-Soto et al., 1988); Av [NiFe] is Azotobacter vinelandii (Menon et al., 1990a); $\mathrm{Rc}$ [NiFe] is Rhodobacter capsulatus (Leclerc et al., 1988); $\mathrm{Rg}$ [NiFe] is Rhodocyclus gelatinosus (Uffen et al., 1990); Ec [NiFe] is Escherichia coli (Menon et al. 1990b).

and negative charges. Fig. 1 shows the sequence alignment of most of the known hydrogenase pro- $\beta$ signal peptides. These signal peptides, from very different bacterial species, share a conserved sequence, the consensus box: RRXFXK. Such a strictly conserved sequence has never before been identified among signal peptides and its presence suggests that the hydrogenase secretion pathway is similarly conserved. This pathway has been studied in some detail (Menon et al., 1991; Van Dongen et al., 1988; Voordouw et al., 1987; Voordouw, 1990). Its most notable feature is that export of both subunits appears cooperative: e.g. export and processing of the small subunit of Escherichia coli [ $\mathrm{NiFe}]$ hydrogenase-I expressed from its cloned gene in $E$. coli is only accomplished when the large subunit gene and other genes of the operon are also expressed (Menon et al., 1991). In the case of expression of genes for [Fe] hydrogenase from Desulfovibrio vulgaris Hildenborough in $E$. coli coexpression of both genes for the small $\beta$ and large $\alpha$ subunit led to export of only a small fraction of $\alpha \beta$ dimer (Van Dongen et al., 1988). However, no export of either subunit was observed when only a single gene was 
expressed. The cooperative nature of the hydrogenase assembly process precludes a study of the unique properties of the signal peptide by monitoring export and activation of the hydrogenase system. The specific properties of the hydrogenase signal peptide can also be studied by fusing a hydrogenase signal peptide to a simpler, exportable protein such as $\beta$-lactamase, that does not require subunit or metal ion cluster assembly for activation.

\section{Methods}

Biochemical reagents. All enzymes were obtained from Pharmacia. Radioactively labelled $\left[\alpha^{-35}\right.$ S]dATP $\left(400 \mathrm{Ci} \mathrm{mmol}^{-1}, 10 \mathrm{mCi} \mathrm{ml}^{-1}\right.$; $1 \mathrm{Ci}=37 \mathrm{GBq}$ ) for dideoxy-sequencing was from Amersham. Tran ${ }^{35} \mathrm{~S}-$ label, containing $70 \% \mathrm{~L}-\left[{ }^{35}\right.$ S $]$ methionine and $15 \% \mathrm{~L}-\left[{ }^{35}\right.$ S $]$ cysteine (1026 Ci mmol$~^{-1}, 10 \mathrm{mCi} \mathrm{ml}^{-1}$ ), used for pulse-chase labelling, was obtained from ICN Biochemicals. Deoxyoligonucleotides were purchased from the Regional DNA Synthesis Laboratory of the University of Calgary. PADAC was from Calbiochem. Prestained SDS-PAGE low molecular mass range standards were from Bio-Rad. Nitrocellulose membrane was from Schleicher and Schuell. Reagent-grade chemicals were obtained from either Fisher, Sigma or Pharmacia.

Strains, vectors and media. The bacterial strains, plasmids and cloning vectors used in this work are described in Table 1 . Aerobic cultures were grown in TY medium containing $10 \mathrm{~g}$ bactotryptone, $5 \mathrm{~g}$ yeast extract and $5 \mathrm{~g} \mathrm{NaCl}$ per litre of water at $\mathrm{pH} 7.4$ (aerobic TY medium). Anaerobic cultures were grown in TY medium supplemented with $30 \mathrm{~mm}$-formate, $0.4 \%$ (w/v) glucose, $2 \mu \mathrm{M}$-sodium selenite and $2 \mu \mathrm{M}$-ammonium molybdate (anaerobic TY medium). Aerobic glucose minimal medium contained $6.25 \mathrm{~g} \mathrm{Na}_{2} \mathrm{HPO}_{4}, 0.75 \mathrm{~g} \mathrm{KH}_{2} \mathrm{PO}_{4}, 2 \mathrm{~g}$ $\mathrm{NaCl}, 0.2 \mathrm{~g} \mathrm{MgSO}_{4} .7 \mathrm{H}_{2} \mathrm{O}, 1 \mathrm{~g}\left(\mathrm{NH}_{4}\right)_{2} \mathrm{SO}_{4}, 10 \mathrm{mg} \mathrm{FeSO}{ }_{4} .7 \mathrm{H}_{2} \mathrm{O}, 10 \mathrm{mg}$ $\mathrm{Na}_{2} \mathrm{MoO}_{4} \cdot 2 \mathrm{H}_{2} \mathrm{O}, 0.16 \mathrm{mg} \mathrm{NaSeO}$ and $4 \mathrm{~g}$ glucose per litre of deionized water at pH 7.4, as described by Lee et al. (1990). Anaerobic glucose minimal medium contained $10 \mathrm{~g}$ glucose per litre and also 30 mM-formate.

Plasmid construction. DNA manipulations were as described by Sambrook et al. (1989). Plasmids were transformed into E. coli TG108 and transformants were selected by their resistance to kanamycin $\left(50 \mu \mathrm{g} \mathrm{ml}^{-1}\right)$ or ampicillin $\left(100 \mu \mathrm{g} \mathrm{ml}^{-1}\right)$. Plasmid pKUL6 (Fig. 2) was constructed as follows. A $1.38 \mathrm{~kb}$ DraI-NdeI fragment containing the plasmid replication origin was obtained from pUC19. End-repair of this fragment and ligation with a $1.2 \mathrm{~kb}$ kanamycin resistance cartridge (BamHI fragment, end-repaired) from pUC-4K gave pKU. Ligation of $K p n I-$ and $S a c l$-digested pKU with the $2 \mathrm{~kb} K p n I-S a c I$ fragment from pWB (Wong, 1989), expressing a levansucrase- $\beta$-lactamase fusion, generated pKUL6 (Fig. 2; Fig. 3b, iv). For construction of pVN1 (Fig. 2), plasmid DV1, containing two $\mathrm{ClaI}$ sites, was partially digested with ClaI (note: only the ClaI site targeted for modification is shown in Fig. 2), end-repaired with Klenow polymerase and dNTPs and BamHI linkers (5'pCCGGATCCGG) ligated into the blunt-ended site. Plasmid pGV21, with a single BamHI site, was digested to completion with $\mathrm{NaeI}$, which leaves the desired $\sim 330$ nucleotide (nt) fragment connected to the $3.0 \mathrm{~kb}$ BLUESCRIPT vector (Stratagene), and religated in the presence of BamHI linkers to give pGV32 with two BamHI sites flanking the desired $\sim 330 \mathrm{nt}$ BamHI fragment. Plasmid pKUL7, obtained by BamHI digestion and religation of pKUL6 (Fig. 2), was digested wtih BamHI and ligated to the $\sim 330 \mathrm{nt}$ BamHI fragment of pGV32 to give pVN1 (Fig. 2; Fig. 3a). Plasmid pVN1, expressing an in-frame fusion of the $[\mathrm{NiFe}]$ hydrogenase signal sequence and mature $\beta$-lactamase from the lac promoter, was verified by restriction digestion
Table 1. Bacterial strains and DNA vectors used in this study

\begin{tabular}{|c|c|}
\hline Strain/vector & Genotype, comments and reference \\
\hline E. coli $\mathrm{TG} 2$ & 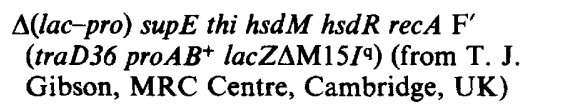 \\
\hline E. coli TG108 & As $E$. coli TG2 but lacking $\mathrm{F}^{\prime}$ (this study) \\
\hline E. coli $\mathrm{RZ} 1032$ & $\begin{array}{l}\text { Hfr KL16 PO/45 [lys A(61-62)] dut-1 ung-1 } \\
\text { thi-1, relAl Zbd-279::Tn10 supE44 } \\
\text { (Kunkel et al., 1987) }\end{array}$ \\
\hline DV1 & $\begin{array}{l}\text { Contains the structural genes for the [NiFe] } \\
\text { hydrogenase from } D \text {. vulgaris Hildenborough } \\
\text { in BLUESCRIPT; Ap } \text { (from A. E. Przybyla, }^{\text {University of Georgia, USA) }}\end{array}$ \\
\hline PGV21 & Derived from DV1; Ap $^{\mathrm{R}}$ (this study) \\
\hline PGV32 & Derived from $\mathrm{pGV} 21 ; \mathrm{Ap}^{\mathrm{R}}$ (this study) \\
\hline pKUL6 & $\begin{array}{l}\text { Contains the levansucrase signal peptide gene } \\
\text { fused in-frame to the gene of mature } \\
\beta \text {-lactamase: } \mathrm{Km}^{\mathrm{R}} \text { (this study) }\end{array}$ \\
\hline pKUL7 & $\begin{array}{l}\text { Derived from pKUL6; contains the gene for } \\
\text { mature } \beta \text {-lactamase without signal peptide; } \\
\mathrm{Km}^{\mathrm{R}} \text { (this study) }\end{array}$ \\
\hline pVN0 & $\begin{array}{l}\text { Derived from pKUL } 7 \text {; contains the wild-type } \\
\text { bla gene; } \mathrm{Km}^{\mathrm{R}} \text { (this study) }\end{array}$ \\
\hline pVN1 & $\begin{array}{l}\text { Derived from pKUL } 7 \text {; contains the }[\mathrm{NiFe}] \\
\text { hydrogenase signal peptide fused in-frame to } \\
\text { the gene of the mature } \beta \text {-lactamase; } \mathrm{Km}^{\mathrm{R}} \\
\text { (this study) }\end{array}$ \\
\hline pIP101 & $\begin{array}{l}\text { Contains the } l a c Z \text { gene; Ap }{ }^{R} \text { (from B. Muller- } \\
\text { Hill, University of Cologne, Germany) }\end{array}$ \\
\hline pWB & (Wong, 1989) \\
\hline $\begin{array}{l}\text { pBR322, pUC19, } \\
\text { M13mp18, pUC-4K }\end{array}$ & $\begin{array}{l}\text { Purchased from Pharmacia (Sambrook et al., } \\
\text { 1989) }\end{array}$ \\
\hline
\end{tabular}

and dideoxynucleotide sequencing of M13 subclones (Sanger et al., 1977). Plasmid pVN0, expressing $\beta$-lactamase with the native signal peptide (Fig. $3 b$, v) from tandemly arranged lac and bla promoters, was obtained by digestion of pVN1 with HindIII and ScaI and ligation with a $546 \mathrm{nt}$ HindIII-ScaI fragment from pBR322.

Oligonucleotide-directed mutagenesis. The Kunkel method (Kunkel et $a l ., 1987)$ was used for mutagenesis. The $330 \mathrm{nt}$ BamHI fragment from $\mathrm{pVN} 1$ was cloned into the replicative form of $\mathrm{M} 13 \mathrm{mp} 18$. The template, obtained from $E$. coli RZ1032, was extended from a hybridized mutagenic primer and ligated using Klenow polymerase, dNTPs, T4 DNA ligase and ATP. Mutagenic primer P49N, 5'GAAGTCGCGT$(A, T)(C, T) G C T G A C G C C$, changed the CGA codon for R(-28) at nt 223-225 (Fig. 3) into either GAA (E), GTA (V), ATA (I) or AAA (K). P50N, 5'GACGCCACGC(A,T)(C,T)CGCCAGACG, changed the CGG codon for $R(-33)$ at $n t$ 208-210 of the signal peptide into either GAG (E), GTG (V), AAG (K) or ATG (M). P51 N, 5'CGGTCAGCTCACGCGCC changed the GCG codon for A(-1) into GAG (E). Mutagenic primer P60N deleted nt 223-240, encoding the consensus residues RRDFLK (Fig. 3b, ii), while P59N deleted nt 161-238, encoding $\mathbf{R}(-49)$ to $\mathbf{L}(-24)$ (Fig. $3 b$, iii). After transfection of the extension-ligation mixtures into $E$. coli TG2, mutant M13 DNAs were identified by dideoxy-sequencing (Sanger et al., 1977). The BamHI insert of the replicative form of the M13 DNA carrying the verified mutation was then ligated to BamHI digested pKUL7. The presence of the insert in the correct orientation was verified by double digestion with ApaI and ScaI (Figs 2 and 3).

Growth of bacteria. E. coli TG108 transformants were grown in $100 \mathrm{ml}$ cultures at $37^{\circ} \mathrm{C}$ in either aerobic or anaerobic TY medium 


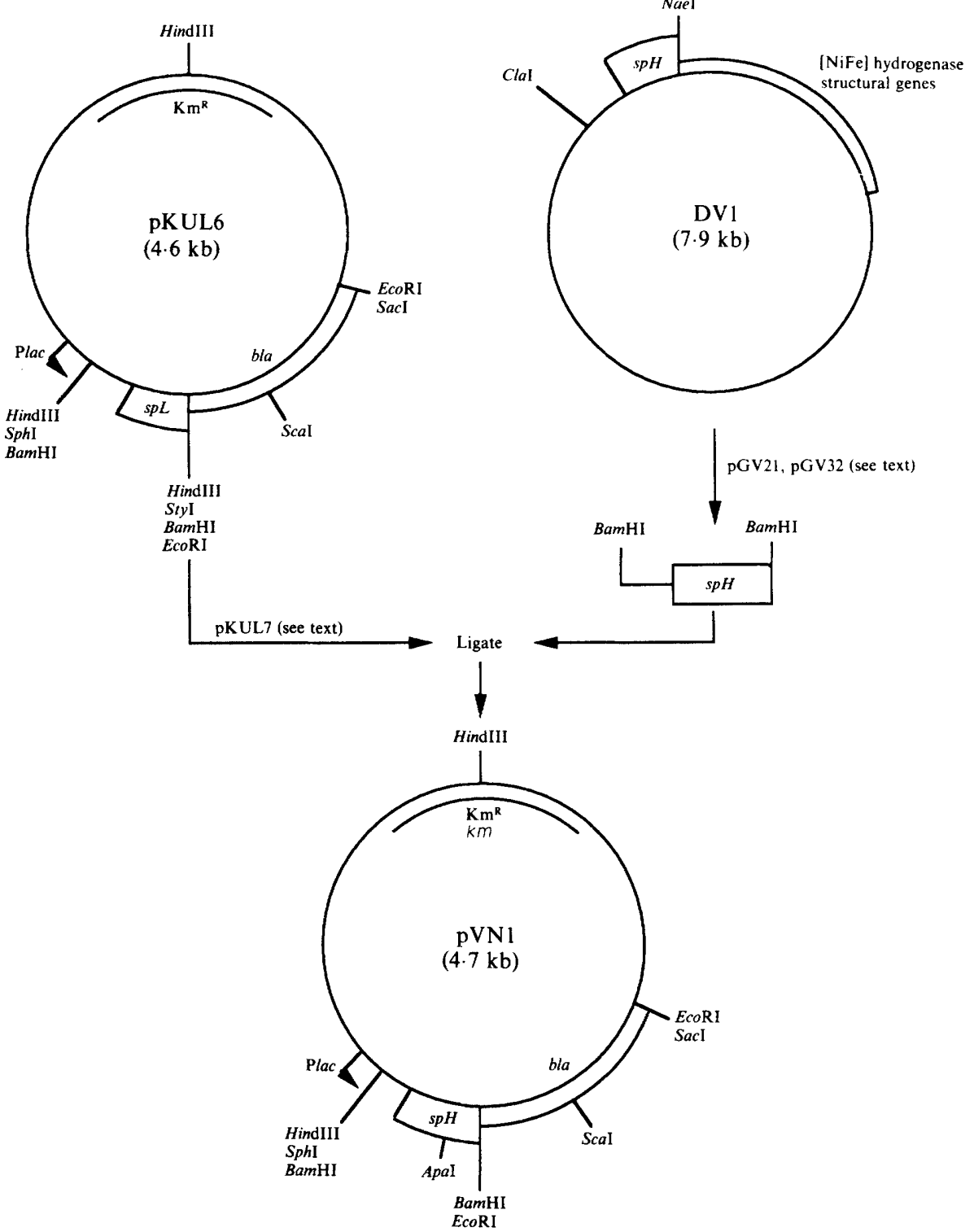

Fig. 2. Construction of pVN1, encoding a fusion of the D. vulgaris Hildenborough [NiFe] hydrogenase signal peptide (spH) to the mature $\beta$-lactamase (bla). Plasmid pKUL6 encodes a similar fusion of the levansucrase signal peptide, which is indicated by $s p L$ (see Fig. $3 b$, iv)

supplemented with $50 \mu \mathrm{g}$ kanamycin $\mathrm{ml}^{-1}$ and shaken at 250 r.p.m. in a New Brunswick G25 shaker for the determination of $\beta$-lactamase activity and Western blot analysis. For pulse-chase experiments, $5 \mathrm{ml}$ cultures of transformants were grown at $37^{\circ} \mathrm{C}$ in either aerobic or anaerobic glucose minimal medium supplemented with $400 \mu \mathrm{g} \mathrm{L}$ proline, $1 \mu \mathrm{g}$ of thiamin and $50 \mu \mathrm{g}$ kanamycin $\mathrm{ml}^{-1}$. Anaerobic growth was in vials closed with rubber stoppers containing medium flushed with nitrogen. Samples of exponential-phase cultures were taken at an $\mathrm{OD}_{600}$ of $0 \cdot 70-0 \cdot 80$.

Pulse-chase labelling. Exponential-phase cells $(5 \mathrm{ml})$ were labelled for 2 min by adding $50 \mu \mathrm{l} \mathrm{Tran}{ }^{35} \mathrm{~S}$-label $\left(10 \mu \mathrm{Ci} \mu \mathrm{l}^{-1}\right)$. Chase was initiated by addition of $50 \mu \mathrm{l}$ minimal medium with unlabelled $\mathrm{L}$-methionine $(250 \mathrm{mM})$ and L-cysteine $(60 \mathrm{mM})$. Samples $(0.5 \mathrm{ml})$ were removed at the indicated times (Fig. 4) and immediately injected into $0.5 \mathrm{ml}$ ice-cold $10 \%(w / v)$ trichloroacetic acid. Precipitates were pelleted, washed with $1 \mathrm{ml}$ ice-cold acetone and dried under vacuum. The dried pellets were resuspended in $50 \mu 10 \mathrm{~mm}$-Tris $/ \mathrm{HCl}, \mathrm{pH} 8.0,1 \%(\mathrm{w} / \mathrm{v}) \mathrm{SDS}, 1 \mathrm{~mm}$ EDTA, and solubilized by heating for $5 \mathrm{~min}$ in a boiling water bath. For immunoprecipitation, a $30 \mu \mathrm{l}$ portion of a solubilized sample was added to $1 \mathrm{ml}$ Triton buffer (Ito $e t$ al., 1981) together with $8 \mu \mathrm{l}$ purified polyclonal anti- $\beta$-lactamase antibodies $\left(0.6 \mathrm{mg} \mathrm{m}^{-1}\right)$. Purification was by immuno-affinity chromatography using $\beta$-lactamase immobilized on CNBr-activated Sepharose-4B (Harlow \& Lane, 1988). Immunoprecipitates were pelleted with Protein A-Sepharose and washed as described by Plückthun \& Knowles (1987). The resulting pellets were boiled for $5 \mathrm{~min}$ with $100 \mu \mathrm{l}$ SDS loading buffer [10\% (w/v) SDS, $250 \mathrm{~mm}$-Tris $/ \mathrm{HCl}$, pH 6.8, $50 \%$ (w/v) glycerol, $0.5 \%$ (w/v) bromo- 
phenol blue, $5 \%(\mathrm{w} / \mathrm{v})$ 2-mercaptoethanol] prior to loading on SDSpolyacrylamide gels. For cell fractionation, $0.5 \mathrm{ml}$ of pulse-chase labelled cells were incubated on ice for $10 \mathrm{~min}$ before the fractionation procedure was started (see below). Periplasmic and spheroplast fractions were similarly precipitated with trichloroacetic acid, washed, dried, resuspended in $50 \mu \mathrm{l} 10 \mathrm{~mm}$-Tris/HCl, $\mathrm{pH} 8.0,1 \%$ (w/v) SDS, $1 \mathrm{~mm}$-EDTA and boiled for $5 \mathrm{~min}$. The membrane fraction was directly resuspended in $50 \mu \mathrm{l} 10 \mathrm{~mm}-\mathrm{Tris} / \mathrm{HCl}, \mathrm{pH} 8.0,1 \%$ (w/v) SDS, $1 \mathrm{~mm}-$ EDTA and boiled for $5 \mathrm{~min}$. Immunoprecipitation and incubation with SDS loading buffer of these fractions were done as described for the whole cells.

Cell fractionation. Periplasmic, spheroplast and membrane fractions were prepared at $4{ }^{\circ} \mathrm{C}$. The pellet of exponential-phase cells was suspended in $300 \mu \mathrm{l} 50 \mathrm{~mm}-\mathrm{Tris} / \mathrm{HCl}, \mathrm{pH} 8.0,10 \%(\mathrm{w} / \mathrm{v})$ sucrose in a microfuge tube. Lysozyme $\left(50 \mu \mathrm{l}, 2 \mathrm{mg} \mathrm{ml}^{-1}\right)$ was then added. Following incubation for $5 \mathrm{~min}, 600 \mu \mathrm{l} 50 \mathrm{mM}$-Tris/HCl, $\mathrm{pH} 8.0$, $15 \mathrm{~mm}$-EDTA and $10 \%(\mathrm{w} / \mathrm{v})$ sucrose was added and incubation continued for $5 \mathrm{~min}$. The microfuge tube was then centrifuged at $16000 \mathrm{~g}$ for $5 \mathrm{~min}$. The supernatant was taken as the periplasmic fraction. The spheroplast pellet was lysed by resuspension in $1 \mathrm{ml} 0.1 \%$ (w/v) Triton X-100 and incubation for $5 \mathrm{~min}$ to obtain the cytoplasmic/ membrane fraction. Fractionation of $E$. coli TG108, transformed with pIP101, carrying the lacZ and bla genes for cytoplasmic $\beta$-galactosidase and periplasmic $\beta$-lactamase, indicated $98 \%$ of the $\beta$-galactosidase activity in the spheroplast pellet, and $95 \%$ of the $\beta$-lactamase activity in the periplasmic fraction. For membrane fraction preparation, the spheroplast pellet was resuspended in $1 \mathrm{ml} 10 \mathrm{mM}-\mathrm{Tris} / \mathrm{HCl}, \mathrm{pH} 8.0$, $1 \mathrm{~mm}$-EDTA, $1 \mu \mathrm{g}$ DNAase $\mathrm{I} \mathrm{ml}^{-1}$ and subjected to three cycles of freezing and thawing. The pellet from centrifugation at $150000 \mathrm{~g}$ for $2 \mathrm{~h}$ was resuspended in $1 \mathrm{ml} 50 \mathrm{~mm}-\mathrm{Tris} / \mathrm{HCl}, \mathrm{pH} 8 \cdot 0,0.5 \mathrm{M}-\mathrm{NaCl}$ and recentrifuged under the same conditions.

Enzyme activity measurements. In assays of $\beta$-lactamase activity PADAC was used as the substrate at a concentration corresponding to $A_{570} \sim 1$ in $100 \mathrm{~mm}$-sodium phosphate buffer, $\mathrm{pH} 7 \cdot 0$. The activity was expressed in units per $10^{8}$ cells, where one unit is defined as the amount of enzyme hydrolysing $1 \mu \mathrm{mol}$ PADAC $\mathrm{min}^{-1}$ and an $\mathrm{OD}_{600}$ of 1 was assumed to correspond to $8 \times 10^{8}$ cells $\mathrm{ml}^{-1}$ (Sambrook et al., 1989).

SDS-PAGE and Western blotting. SDS-PAGE was done on $12 \%$ (w/v) polyacrylamide running gels according to Laemmli (1970). Molecular masses of sample proteins were determined relative to prestained SDS-PAGE low-range molecular mass standards. For autoradiography, gels were shaken in $10 \%(\mathrm{v} / \mathrm{v})$ glacial acetic acid, $20 \%$ (v/v) methanol for $30 \mathrm{~min}$, then in $5 \%(\mathrm{v} / \mathrm{v})$ glycerol, $50 \%(\mathrm{v} / \mathrm{v})$ methanol for $30 \mathrm{~min}$, dried and exposed to $\mathrm{X}$-ray film for $2-3 \mathrm{~d}$. For Western blotting analysis, $100 \mu \mathrm{l}$ SDS loading buffer was added directly to $1 \mathrm{ml}$ samples of exponential-phase aerobic or anaerobic TY cultures. Following boiling of the samples for $5 \mathrm{~min}$, SDS-PAGE and electrophoretic transfer to nitrocellulose (Towbin et al., 1979), the nitrocellulose filters were processed as reported elsewhere (Pollock et $a l ., 1989)$ except that purified polyclonal anti- $\beta$-lactamase serum was used as the primary antibody at a 1:500 dilution. An alkalinephosphatase-conjugated goat anti-rabbit IgG was used as the secondary antibody and the blot was immunostained with nitroblue tetrazolium and 5-bromo-4-chloro-3-indolyl phosphate.

\section{Results}

\section{Construction of $p V N 1$}

The relevant part of the nucleotide sequence of pVN1, constructed as outlined in Fig. 2, is shown in Fig. 3(a).
The construction procedure generated codons for five additional amino acid residues: PGSGI (Fig. $3 b, \mathrm{i}:+6$ to +10$)$. The amino acid sequence of $D$. vulgaris $[\mathrm{NiFe}]$ hydrogenase ends at $R(+5)$, while that of $\beta$-lactamase starts at $P(+11)$, which is residue $(+2)$ of mature $\beta$-lactamase (Fig. $3 b, v$ ). The construction conserves the hydrogenase signal peptide cleavage site. A ribosome-binding site (RBS), AAGGAGG, is present 6 nucleotides upstream from the ATG initiation codon of the hydrogenase signal peptide. Expression of the bla gene fusion is under control of the lac promoter (Fig. 2). Addition of IPTG is not necessary for maximal expression in $E$. coli $\mathrm{TG} 108$, since the lacI $^{\mathrm{q}}$ gene encoding lac repressor is deleted from this strain (Table 1).

\section{Pulse-chase labelling analysis of fusion protein processing and export}

Because $E$. coli specifically expresses hydrogenase activity under anaerobic conditions, experiments were carried out under both aerobic and anaerobic conditions. The results of several pulse-chase labelling experiments are shown in Fig. 4. The purified polyclonal anti- $\beta$ lactamase serum specifically immunoprecipitated five forms of $\beta$-lactamase, a-e, from $E$. coli TG108(pVN1). Form c, molecular mass $29.0 \mathrm{kDa}$, only appeared after a period of chase, was the only form present in the periplasmic fraction (Fig. $4 b$ ) and represents, therefore, the processed and exported form of $\beta$-lactamase. Form $b$ (molecular mass $34.5 \mathrm{kDa}$ ) disappeared during pulsechase labelling, in parallel with the appearance of the periplasmic form c (Fig. $4 a, c$ ). Its cytoplasmic location (Fig. $4 b$ ) and molecular mass indicate it to represent the fusion protein as translated in Fig. 3(a). Additional evidence that form $\mathbf{b}$ is converted into $\mathbf{c}$ by proteolytic processing at the site indicated in Fig. 3 came from mutagenesis of the codon for $A(-1)$. The mutant expressed the $34.5 \mathrm{kDa}$ pre- $\beta$-lactamase (form b) but the $\mathrm{A}(-1) \mathrm{E}$ mutation prevented processing to form $\mathbf{c}$ (not shown). Form a (molecular mass $38.0 \mathrm{kDa}$ ), which disappeared with a similar rate as b (Fig. $4 a, c$ ), could result from translation initiation at a TTG codon (nt 85). The sequence AGGTG (nt 70) is complementary to the $3^{\prime}$ end of E. coli $16 \mathrm{~S}$ rRNA and is spaced the optimal distance of $10 \mathrm{nt}$ from the TTG codon, which can serve as an initiation codon in $E$. coli. Alternatively, translation may initiate at the ATG codon at $\mathrm{nt} 88$. The resulting polypeptide has a calculated molecular mass of $37.0 \mathrm{kDa}$. Forms d and e (28.0 and $26.0 \mathrm{kDa})$ remained relatively constant during pulse-chase labelling (Fig. 4a) and were mainly located in the cytoplasm (Fig. 4b). They were the only forms observed in experiments with $E$. coli TG108(pKUL7), which lacks a signal peptide, and must 
(a)

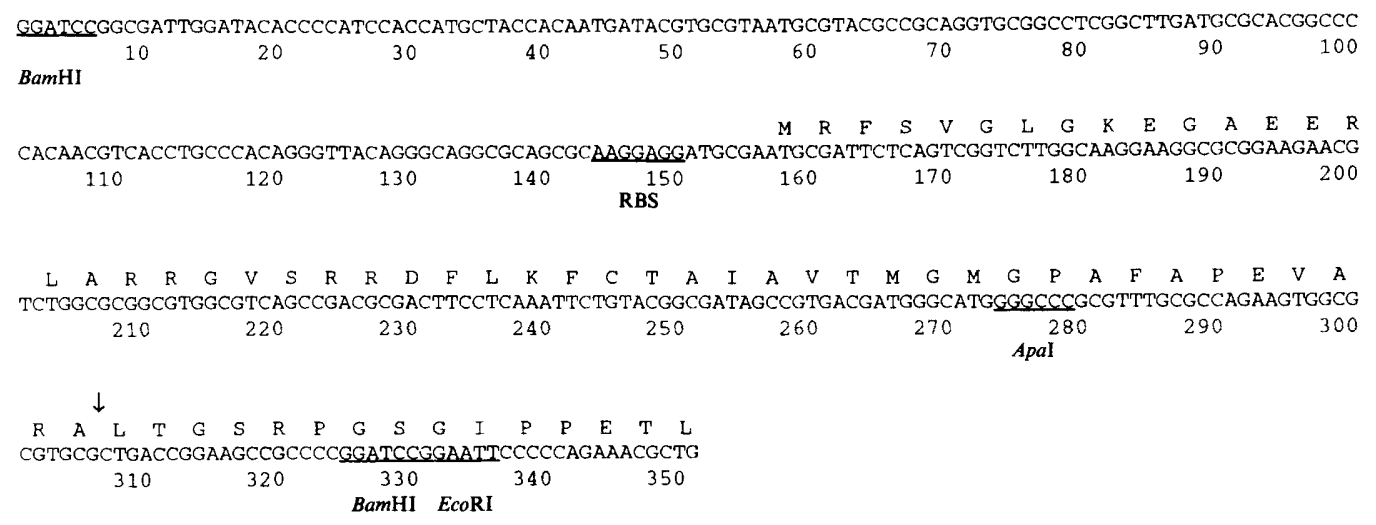

(b)

(i)

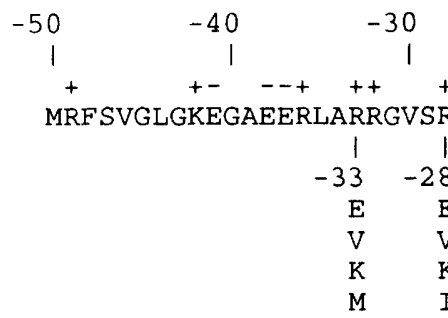

(ii)

$-20 \quad-10$

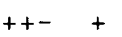

(iii)

(iv)

(v)
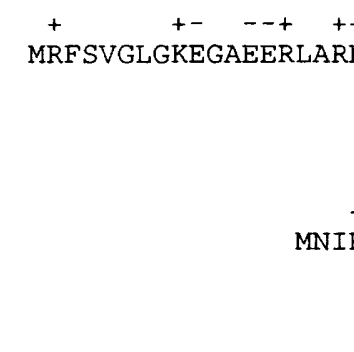

Fig. 3. (a) Nucleotide sequence of a $351 \mathrm{nt}$ portion of plasmid pVN1, encoding the $\mathrm{NH}_{2}$ terminus of the [NiFe] hydrogenase signal peptide- $\beta$-lactamase fusion protein, which is translated using the single-letter amino acid code. The hydrogenase signal peptidase cleavage site is indicated ( $\downarrow$ ), as are the sites for restriction endonucleases BamHI, ApaI and EcoRI. A putative ribosome-binding site (RBS) is also indicated. (b) (i) Mutations generated in the hydrogenase signal sequence at $R(-33), R(-28)$ and A( $(-1)$. (ii), (iii) Deletion mutations of the hydrogenase signal sequence. (iv) Bacillus subtilis levansucrase signal sequence- $\beta$-lactamase fusion expressed by plasmid pKUL6 (Fig. 2). (v) Native signal sequence- $\beta$-lactamase expressed by pVN0.

result from translation initiation at positions downstream from nt 157.

Pulse-chase labelling of $E$. coli TG108(pVN1) (Fig. 4a) indicated that the periplasmic $\beta$-lactamase, form c, appeared at 10-20 min after the start of the chase. Repeating the same experiment with $E$. coli TG108(pVN0), encoding $\beta$-lactamase with its native signal peptide (Fig. $3 b$, v), showed more rapid and efficient processing of pre-Bla (molecular mass $31.5 \mathrm{kDa}$ ) to Bla (molecular mass $28.9 \mathrm{kDa}$ ). The cytoplasmic form e, molecular mass $26 \mathrm{kDa}$, was also observed but in lower concentration (Fig. $4 d$ ). Comparing the results of Fig. $4(a)$ and $4(d)$ indicates that the form b to conversion in E. coli TG108(pVN1) is clearly slower and less efficient than the conversion of pre-Bla to Bla in $E$. coli TG108(pVN0). In E. coli, hydrogenase is specifically expressed under anaerobic conditions in the presence of glucose or formate (Sawers et al., 1985). Interestingly, processing of the fusion protein occurred more rapidly under these conditions (Fig. $4 c$ : form $\mathrm{c}$ appears after $2-5 \mathrm{~min}$ ), compared to aerobic conditions (Fig. 4a). 

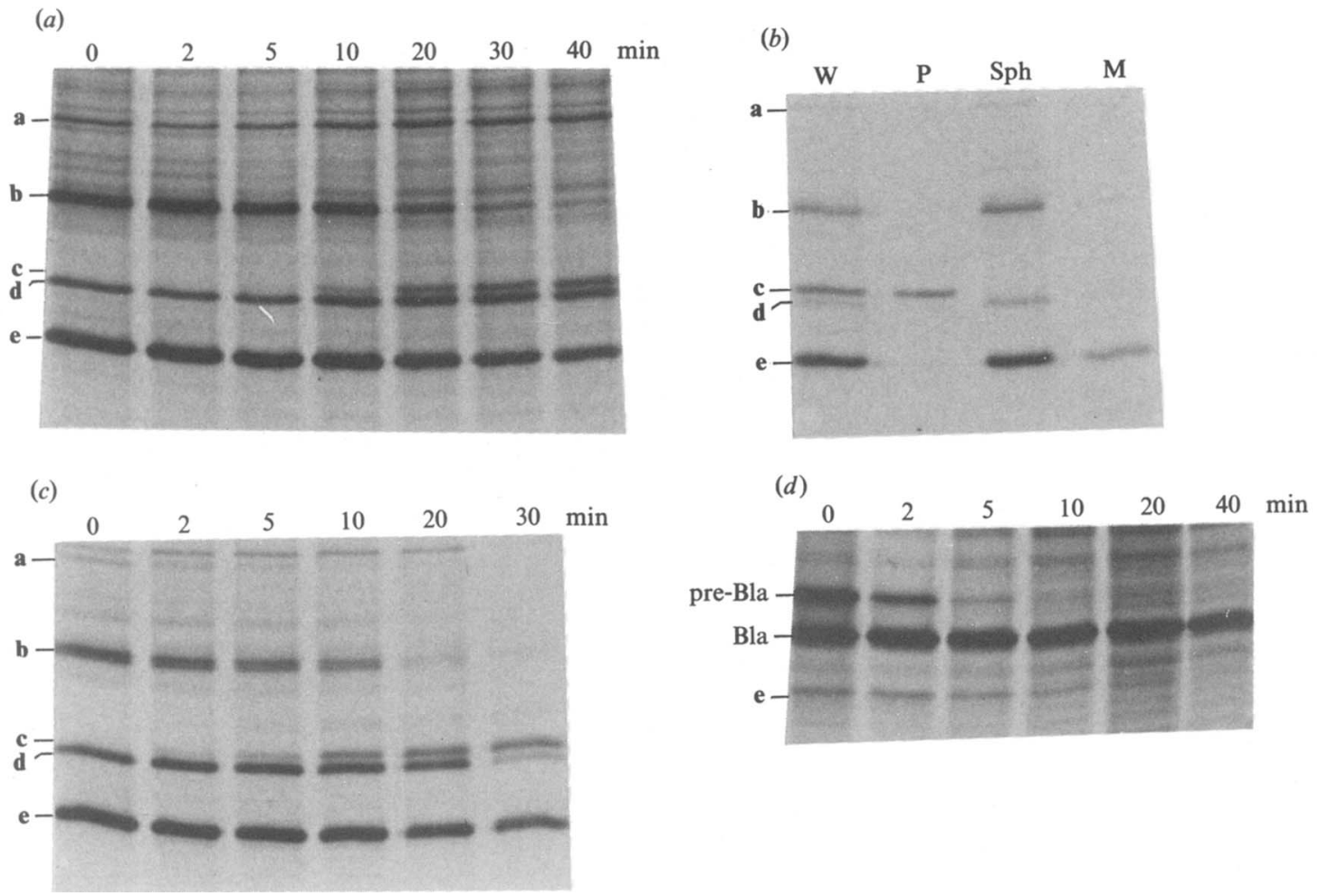

Fig. 4. Pulse-chase labelling of $\beta$-lactamase proteins. Following a 2 min pulse with $\left[{ }^{35} S\right]$ methionine/cysteine the cells were chased with non-radioactive methionine/cysteine for the indicated times. (a) E. coli TG108(pVN1) grown in aerobic glucose minimal medium. (b) Fractionation of whole cells (W) of E. coli TG108(pVN1) grown in aerobic glucose minimal medium after a 20 min chase into a periplasmic (P), spheroplast (Sph) and membrane (M) fraction. The spheroplast fraction contains both membrane and cytoplasm fractions. (c) $E$. coli TG108(pVN1) grown in anaerobic glucose minimal medium. (d) E. coli TG108(pVN0) grown in aerobic glucose minimal medium. Bands $b$ and $c$ are the precursor $(34.5 \mathrm{kDa})$ and processed $(29 \mathrm{kDa})$ forms of the $\beta$-lactamase fusion protein. Bands $\mathbf{a}, \mathbf{d}$ and $e$ of 38,28 and $26 \mathrm{kDa}$, respectively, also react specifically with the serum and are discussed in the text. The native precursor (pre$\mathrm{Bla}, 31.5 \mathrm{kDa})$ and its processed form (Bla, $29 \mathrm{kDa})$ are indicated.

Site-directed mutagenesis of the consensus box residue $R(-28)$

To identify which parts of the hydrogenase signal sequence are important for export of the fusion protein some initial deletion studies were carried out. Pulsechase experiments with a variant of pVN1 in which the consensus box sequence was deleted (Fig. $3 b$, ii) indicated absence of processing of the precursor form $\mathbf{b}$ (molecular mass $33.9 \mathrm{kDa}$ ) to c (not shown). Deletion of most of the $\mathrm{NH}_{2}$-terminal charged region (Fig. $3 b$, iii) to a signal peptide of 24 residues, similar in length to the native signal ( 23 residues) also inhibited processing of form b (molecular mass $31.6 \mathrm{kDa}$ ). These results indicate that the presence of the consensus box sequence is important for fusion protein processing, but do not prove that the the strictly conserved hydrogenase signal peptide consensus box RRXFXK (Fig. 1) is required. We therefore constructed four mutants which synthesized a fusion protein in which $\mathrm{R}(-28)$ was replaced by either E, V, K or I. Rather than by pulse-chase experiments the effect of each mutation on the export of the $\beta$-lactamase fusion protein was determined by $\beta$ lactamase activity measurements of cell fractions, while processing was monitored by Western blot analysis of whole cells. The wild-type hydrogenase signal peptide directed $60 \%$ of the total $\beta$-lactamase activity to the periplasm under aerobic and $86 \%$ under anaerobic conditions. The absolute value of the periplasmic $\beta$ lactamase activity increased threefold, from 0.18 to 0.55 units per $10^{8}$ cells, under anaerobic conditions (Table 2). Western blotting experiments with wild-type signal peptide indicated more complete processing of the precursor form $\mathbf{b}$ to $\mathbf{c}$ under anaerobic conditions (Fig. 5, lanes 1 and 2): form $\mathbf{b}$ cannot be detected in Western blot experiments with wild-type signal peptide under these conditions. These results agree with the observation of more rapid fusion protein processing in pulse-chase experiments under anaerobic conditions. The classical native or levansucrase signal peptides (Fig. $3 b$, iv and v) 


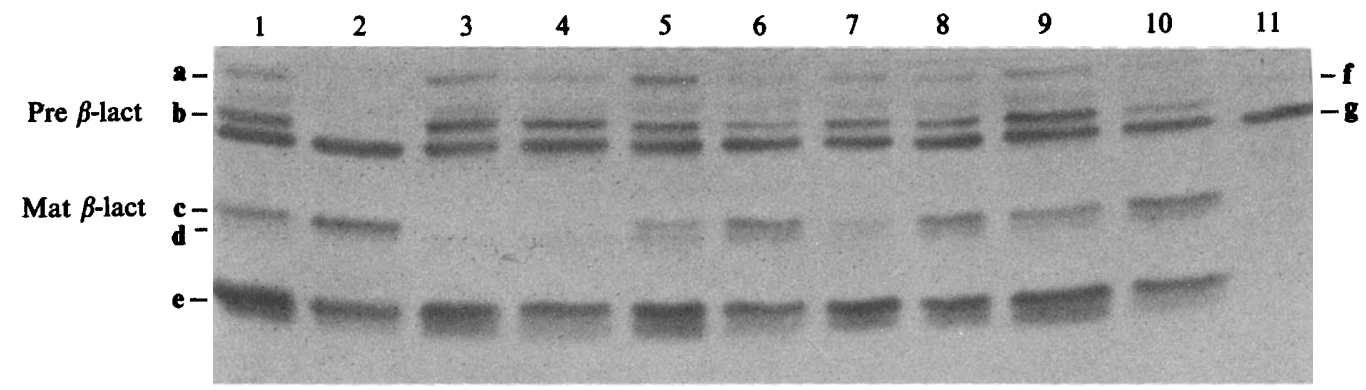

Fig. 5. Effect of mutation of signal peptide residue $\mathrm{R}(-28)$ on the processing of the $\beta$-lactamase fusion protein. Whole cells of $E$. coli TG108 transformed with pVN1 or a mutant form of this plasmid, grown in aerobic (odd-numbered lanes) or anaerobic (even-numbered lanes) TY medium were analysed by SDS-PAGE and Western blotting, using a polyclonal $\beta$-lactamase antiserum. Lanes 1 and 2 , wildtype; lanes 3 and $4, R(-28) E$; lanes 5 and $6, R(-28) \mathrm{V}$; lanes 7 and $8, R(-28) I$; lanes 9 and $10, R(-28) \mathrm{K}$. Lane 11 represents untransformed $E$. coli TG108. The various forms a-e of $\beta$-lactamase are explained in the legend to Fig. 4 . Pre $\beta$-lact and Mat $\beta$-lact represent the precursor and the mature forms $b$ and $\mathbf{c}$ of $\beta$-lactamase respectively. Bands $f$ and $g$ react non-specifically with the serum and are also found in whole cells of $E$. coli TG108 without plasmid (lane 11).

directed $95 \%$ of the $\beta$-lactamase activity to the periplasm under both aerobic and anaerobic conditions. This higher fraction is again consistent with the more rapid processing observed in Fig. 4(d).

The $\beta$-lactamase activities measured for the $\mathrm{R}(-28)$ mutants are summarized in Table 2. The $R(-28) \mathrm{E}$ mutation strongly affected the export of $\beta$-lactamase to the periplasm. Compared to the wild-type signal peptide, we observed an $84-93 \%$ decrease of periplasmic $\beta$ lactamase activity. The values obtained for this mutant were actually very similar to those for $E$. coli TG108(pKUL7), where the signal peptide has been deleted. The other mutations, $R(-28) \mathrm{V}, \mathrm{R}(-28) \mathrm{I}$ and $\mathbf{R}(-28) \mathrm{K}$, had less strong effects (Table 2).

Western blotting indicated that the $\mathrm{R}(-28) \mathrm{E}$ mutation (Fig. 5: lanes 3, 4) completely prevented processing of pre- $\beta$-lactamase to form $\mathbf{c}$. No differences could be noted between aerobic (lane 3), and anaerobic (lane 4) growth conditions, in agreement with the results of the activity measurements. The effects of the other mutations are less pronounced (lanes 5-10). Under anaerobic conditions, pre- $\beta$-lactamase (form $b$ ) was only partially processed for these mutations (lanes 6, 8 and 10) compared to the wildtype control (lane 2).

\section{Site-directed mutagenesis of $R(-33)$}

To verify the specificity of the effects of the $R(-28)$ mutation, we mutated another arginine residue, located outside the consensus box. $R(-33)$ was considered to be a good control mutation, since, like $\mathbf{R}(-28)$, it is the first of an arginine doublet and the sequence on its $\mathrm{COOH}$ terminal side (RRXXXR) is similar to that on the COOH-terminal side of $R(-28)$, which is RRXXXK (Fig. $3 b$ ). Compared to the wild-type signal peptide, mutations $\mathbf{R}(-33) \mathrm{E}, \mathbf{R}(-33) \mathrm{M}$ and $\mathrm{R}(-33) \mathrm{V}$ decreased the
Table 2. Effects of hydrogenase signal peptide mutations on $\beta$-lactamase export

The codons for $\mathbf{R}(-28)$ and $\mathbf{R}(-33)$ were changed by site-directed mutagenesis. Partitioning of the $\beta$-lactamase activity expressed by the resulting derivatives of $\mathrm{pVN} 1$, transformed into $E$. coli TG108, was determined following growth in either aerobic or anaerobic TY medium.

\begin{tabular}{|c|c|c|c|c|}
\hline \multirow[b]{2}{*}{ Mutation } & \multirow{2}{*}{$\begin{array}{l}\text { Growth } \\
\text { condition }\end{array}$} & \multicolumn{2}{|c|}{$\beta$-Lactamase activity* } & \multirow{2}{*}{$\begin{array}{c}\text { Periplasmic } \\
\text { activity } \\
\text { ratiof }\end{array}$} \\
\hline & & Cytoplasmic $†$ & Periplasmic & \\
\hline Wild-type & $\begin{array}{l}\text { Anaerobic } \\
\text { Aerobic }\end{array}$ & $\begin{array}{l}0.09 \\
0.12\end{array}$ & $\begin{array}{l}0.55 \\
0.18\end{array}$ & $\begin{array}{l}100 \\
100\end{array}$ \\
\hline $\mathbf{R}(-28) \mathrm{E}$ & $\begin{array}{l}\text { Anaerobic } \\
\text { Aerobic }\end{array}$ & $\begin{array}{l}0 \cdot 16 \\
0 \cdot 12\end{array}$ & $\begin{array}{l}0.04 \\
0.03\end{array}$ & $\begin{array}{r}7 \\
16\end{array}$ \\
\hline $\mathbf{R}(-28) \mathrm{V}$ & $\begin{array}{l}\text { Anaerobic } \\
\text { Aerobic }\end{array}$ & $\begin{array}{l}0 \cdot 12 \\
0 \cdot 17\end{array}$ & $\begin{array}{l}0 \cdot 24 \\
0 \cdot 13\end{array}$ & $\begin{array}{l}43 \\
72\end{array}$ \\
\hline $\mathbf{R}(-28) \mathbf{I}$ & $\begin{array}{l}\text { Anaerobic } \\
\text { Aerobic }\end{array}$ & $\begin{array}{l}0 \cdot 10 \\
0 \cdot 12\end{array}$ & $\begin{array}{l}0 \cdot 22 \\
0.09\end{array}$ & $\begin{array}{l}40 \\
50\end{array}$ \\
\hline $\mathbf{R}(-28) \mathbf{K}$ & $\begin{array}{l}\text { Anaerobic } \\
\text { Aerobic }\end{array}$ & $\begin{array}{l}0.08 \\
0.09\end{array}$ & $\begin{array}{l}0 \cdot 22 \\
0 \cdot 13\end{array}$ & $\begin{array}{l}40 \\
72\end{array}$ \\
\hline$R(-33) E$ & $\begin{array}{l}\text { Anaerobic } \\
\text { Aerobic }\end{array}$ & $\begin{array}{l}0.04 \\
0 \cdot 13\end{array}$ & $\begin{array}{l}0.44 \\
0.14\end{array}$ & $\begin{array}{l}73 \\
77\end{array}$ \\
\hline $\mathbf{R}(-33) \mathrm{V}$ & $\begin{array}{l}\text { Anaerobic } \\
\text { Aerobic }\end{array}$ & $\begin{array}{l}0 \cdot 10 \\
0 \cdot 08\end{array}$ & $\begin{array}{l}0 \cdot 50 \\
0 \cdot 14\end{array}$ & $\begin{array}{l}91 \\
77\end{array}$ \\
\hline $\mathbf{R}(-33) \mathbf{M}$ & $\begin{array}{l}\text { Anaerobic } \\
\text { Aerobic }\end{array}$ & $\begin{array}{l}0.06 \\
0.06\end{array}$ & $\begin{array}{l}0.41 \\
0 \cdot 12\end{array}$ & $\begin{array}{l}74 \\
66\end{array}$ \\
\hline $\mathbf{R}(-33) \mathrm{K}$ & $\begin{array}{l}\text { Anaerobic } \\
\text { Aerobic }\end{array}$ & $\begin{array}{l}0 \cdot 15 \\
0 \cdot 17\end{array}$ & $\begin{array}{l}0.57 \\
0.21\end{array}$ & $\begin{array}{l}104 \\
116\end{array}$ \\
\hline $\begin{array}{l}\text { Signal peptide } \\
\text { deleted } \S\end{array}$ & $\begin{array}{l}\text { Anaerobic } \\
\text { Aerobic }\end{array}$ & $\begin{array}{l}0 \cdot 18 \\
0 \cdot 14\end{array}$ & $\begin{array}{l}0.02 \\
0.02\end{array}$ & $\begin{array}{r}4 \\
11\end{array}$ \\
\hline
\end{tabular}

* $\beta$-Lactamase activity is expressed in mmol PADAC $\min ^{-1}\left(10^{8}\right.$ cells) $)^{-1}$.

† This includes both cytoplasmic and membrane-bound activities. $\ddagger$ Ratio [(periplasmic activity)/(periplasmic activity of wild-type)] $\times 100$.

$\S$ Data for $E$. coli TG108(pKUL7).

export of $\beta$-lactamase activity by $10-34 \%$. The mutation $\mathbf{R}(-33) \mathrm{K}$ had no effect. Analysis by Western blotting of whole-cell fractions did not reveal significantly different processing of mutant signal sequences relative to the 
wild-type signal sequence, under either aerobic or anaerobic conditions (data not shown). Thus, while some effects of mutating $\mathbf{R}(-33)$ were observed, they were small compared to those caused by mutating the consensus box residue $\mathbf{R}(-28)$.

\section{Discussion}

One of the most striking features in all periplasmic hydrogenase small subunit signal peptides characterized to date is the presence of the consensus box RRXFXK. This element is separated by a conserved number of residues from the signal peptide cleavage site, 21 residues in the [Fe] and 22 residues in the [NiFe] and [NiFeSe] hydrogenases (Fig. 1), and precedes the hydrophobic core of the signal peptide. The length variation of hydrogenase signal peptides ( $32-50$ amino acids) is thus principally caused by a variable $\mathrm{NH}_{2}$-terminal part preceding the positively charged consensus box. For [Fe] and $[\mathrm{NiFeSe}]$ hydrogenase signal peptides (32-34 residues), no extra charges are present in this region (4-7 residues). However, in [NiFe] hydrogenase signal peptides (41-50 residues), this region (14-22 residues) contains several positively and negatively charged amino acid side chains. Interestingly, these signal peptides exhibit some structural homology with the transit peptides which target proteins to intermembrane spaces of eukaryotic organelles such as the yeast mitochondrial cytochrome $c_{1}$. These mitochondrial signal peptides also have a long charged $\mathrm{NH}_{2}$-terminal portion preceding their hydrophobic core (Pugsley, 1989). Whereas periplasmic [Fe] and [NiFeSe] hydrogenases seem to be restricted to sulphate-reducing bacteria of the genus Desulfovibrio (Voordouw et al., 1990), the [NiFe] hydrogenase is widely distributed among micro-organisms, including sulphate-reducing bacteria, nitrogen-fixing bacteria, photosynthetic bacteria and enterobacteria (Fig. 1).

We have shown here that the hydrogenase signal peptide functions also in the export of $\beta$-lactamase, although less well than either the native $\beta$-lactamase or the $B$. subtilis levansucrase signal peptides (Fig. $3 b$, iv and v). Despite this limited efficiency the fusion protein system shows two features that indicate it to mimic hydrogenase export correctly: (i) export and processing of the fusion protein is dependent on the consensus box sequence, which cannot be deleted or mutagenized, and (ii) export and processing in E. coli appears more efficient under anaerobic conditions.

With respect to (i) we have shown that mutation of $\mathbf{R}(-28)$, the first residue of the consensus box, strongly inhibits export and processing of the fusion protein (Table 2, Fig. 5). These results are quite unusual for a signal peptide. Indeed, several studies on the positively charged $\mathrm{NH}_{2}$-terminal part of $E$. coli signal peptides have shown that the number of positive charges is unimportant as long as the global charge of the $\mathrm{NH}_{2}$ terminal region remains positive (Kadonaga et al., 1985; Lehnhardt et al., 1988; Puziss et al., 1989). In some cases, even a shift from a global positive to a global neutral charge does not significantly affect the efficiency of export (Vlasuk et al., 1983). Mutations known to generate strong defects in protein export are mostly localized in the hydrophobic core of the signal peptide, changing a hydrophobic residue to a polar one (Gennity et al., 1990). The mutation R(-28)E does not reverse the charge of the $\mathrm{NH}_{2}$-terminal part of the signal peptide: its global charge remains still positive. Also, three other glutamate residues, $E(-41), E(-38)$ and $E(-37)$, are already present in this region. The strong inhibition of export and processing therefore indicates that the consensus box residue $R(-28)$ plays a crucial role in the export process, especially in view of the fact that mutation of $\mathbf{R}(-33)$ has little effect.

With respect to (ii) it is important to establish whether fusion protein expression (the sum of transcription and translation, as well as mRNA and protein degradation) is altered in shifting from aerobic to anaerobic growth conditions. The data in Fig. 5, lanes 3 and 4, indicate that expression of the $\mathbf{R}(-28) \mathrm{E}$ mutant form of the fusion protein, which is not processed, is unaltered. Since all other constructs for which data are shown in Fig. 5 differ only in the codon for $R(-28)$, and since large variations in either transcription or translation rates due to these minor template changes appear unlikely, it is reasonable to assume that the expression levels in all of the samples analysed in Fig. 5 were similar and that the observed shifts were caused by changes in fusion protein processing rates. An increased processing rate under anaerobic conditions is evident from pulse-chase experiments. Although the two- to fivefold rate increase observed is modest, it accounts for the threefold increased level of wild-type periplasmic $\beta$-lactamase activity observed under anaerobic conditions. (Table 2). The question is, why do anaerobic conditions increase the rate of fusion protein processing in E. coli? Genetic studies have shown that many accessory genes are involved in the synthesis of active hydrogenases in $E$. coli in addition to the structural genes for these enzymes (e.g. Bohm et al., 1990; Lutz et al., 1991; Menon et al., 1991). Their specific roles are largely unknown. We speculate that one of the accessory genes encodes a protein that specifically binds to the hydrogenase signal peptide consensus box and facilitates the export and processing of hydrogenase. In $E$. coli, expression of hydrogenase structural and accessory genes occurs only under anaerobic conditions (Sawers et al., 1985; Sawers \& Boxer, 1986), and we 
postulate that the changed molecular composition of the $E$. coli cell under these conditions is responsible for the increased rate of fusion protein processing.

This work was supported by grants from the Natural Science and Engineering Research Council of Canada (NSERC) to G.V. and S. L.W.; V.N. was supported by an Alberta Heritage Foundation for Medical Research (AHFMR) postdoctoral fellowship. We thank Dr A. E. Przybyla, Department of Biochemistry, University of Georgia, for plasmid DV1.

\section{References}

BöHM, R., SAUTER, M. \& BöcK, A. (1990). Nucleotide sequence and expression of an operon in Escherichia coli coding for formate hydrogenylase components. Molecular Microbiology 4, 231-243.

DeCKers, H. M., Wilson, F. R. \& Voordouw, G. (1990). Cloning and sequencing of a $[\mathrm{NiFe}]$ hydrogenase operon from Desulfovibrio vulgaris Miyazaki F. Journal of General Microbiology 136, 2021-2028.

Fauque, G., Peck, H. D., Jr, Moura, J. J. G., Huynh, B. H., Berlier, Y., DerVartanian, D. V., Teixeira, M., Przybyla, A. E., Lespinat, P. A., Moura, I. \& Le Gall, J. (1988). The three classes of hydrogenases from sulfate reducing bacteria of the genus Desulfovibrio. FEMS Microbiology Reviews 54, 299-344.

Gennity J., Goldstein, J. \& INouye, M. (1990). Signal peptide mutants of Escherichia coli. Journal of Bioenergetics and Biomembranes 22, 233-269.

GiERASCH, L. M. (1989). Signal sequences. Biochemistry 28, 923-930.

Harlow, E. \& LANE, D. (1988). Antibodies : a Laboratory Manual. Cold Spring Harbor, NY: Cold Spring Harbor Laboratory.

ITO, K., BASSFORD, P. J., JR \& BECKWITH, J. (1981). Protein localization in $E$. coli: is there a common step in the secretion of periplasmic and outer-membrane proteins? Cell 24, 707-717.

Kadonaga, J. T., PlüCxthun, A. \& Knowles, J. R. (1985). Signal sequence mutants of $\beta$-lactamase. Journal of Biological Chemistry $\mathbf{2 6 0}$, 16192-16199.

Kunkel, T. A., RoberTs, J. D., \& ZaKour, R. A. (1987). Rapid and efficient site-specific mutagenesis without phenotypic selection. Methods in Enzymology 154, 367-382.

LAEMMLI, U. K. (1970). Cleavage of structural proteins during the assembly of the head of bacteriophage T4. Nature, London 227, 680685.

Leclerc, M., Colbeau, A., Cauvin, B. \& Vignais, P. M. (1988). Cloning and sequencing of the genes encoding the large and the small subunits of the $\mathrm{H}_{2}$ uptake hydrogenase (hup) of Rhodobacter capsulatus. Molecular and General Genetics 214, 97-108.

LEE, J.-H., WendT, J. C. \& Shanmugam, K. T. (1990). Identification of a new gene, molR, essential for utilization of molybdate in Escherichia coli. Journal of Bacteriology 172, 2079-2087.

Lehnhardt, S., Pollitt, N. S., Goldstein, J. \& Inouye, M. (1988). Modulation of the effects of mutations in the basic region of the OmpA signal peptide by the mature portion of the protein. Journal of Biological Chemistry 263, 10300-10303.

Lutz, S., Jacobi, A., Schlensog, V., Böhm, R., SAWers, G. \& Böck, A. (1991). Molecular characterization of an operon (hyp) necessary for the activity of the three hydrogenase isoenzymes in Escherichia coli. Molecular Microbiology 5, 123-135.

Menon, A. L., Stults, L. W., Robson, R. L. \& Mortenson, L. E. $(1990 a)$. Cloning, sequencing and characterization of the [NiFe] hydrogenase-encoding structural genes (hox $\mathrm{K}$ and hox $\mathrm{G}$ ) from Azotobacter vinelandii. Gene $96,67-74$.

Menon, N. K., Robbins, J., PeCK, H. D., JR, Chatelus, C. Y., Choi, E. S. \& Przybyla, A. E. $(1990 \mathrm{~b})$. Cloning and sequencing of a putative Escherichia coli $[\mathrm{NiFe}]$ hydrogenase-1 operon containing six open reading frames. Journal of Bacteriology 172, 1969-1977.
Menon, N. K., Robbins, J., Wendt, J. C., Shanmugan, K. T. \& PRZYBYLA, A. E. (1991). Mutational analysis and characterization of the Escherichia coli hya operon, which encodes [NiFe] hydrogenase 1. Journal of Bacteriology 173, 4851-4861.

Nivière, V., Bernadac, A., Forget, N., Fernández, V. M. \& HATCHIKIAN, C. E. (1991). Localization of hydrogenase in Desulfovibrio gigas cells. Archives of Microbiology 155, 579-586.

PLÜKThun, A. \& KNOWLES, J. R. (1987). The consequences of stepwise deletions from the signal-processing site of $\beta$-lactamase. Journal of Biological Chemistry 262, 3951-3957.

Pollock, W. B. R., Chemerika, P. J., Forrest, M. E., Beatty, J. T. \& VoORDOUW, G. (1989). Expression of the gene encoding cytochrome $c_{3}$ from Desulfovibrio vulgaris Hildenborough in Escherichia coli: export and processing of the apoprotein. Journal of General Microbiology 135, 2319-2328.

Pugsley, A. P. (1989). Protein Targeting. San Diego: Academic Press.

Puziss, J. W., Fikes, J. D. \& BASSFORD, P. J., JR (1989). Analysis of mutational alterations in the hydrophilic segment of the maltosebinding protein signal peptide. Journal of Bacteriology 171, 23032311.

Rhode, M., Fürstenau, U., Mayer, F., Przybyla, A. E., Peck, H. D., JR, Le Gall, J., Choi, E. S. \& Menon, N. K. (1990). Localization of membrane-associated $[\mathrm{NiFe}]$ and $[\mathrm{NiFeSe}]$ hydrogenases of Desulfovibrio vulgaris using immunoelectron microscopic procedures. European Journal of Biochemistry 191, 389-396.

Rousset, M., Dermoun, Z., Hatchikian, C. E. \& Bélaich, J. P. (1990). Cloning and sequencing of the locus encoding the large and small subunit genes of the periplasmic [NiFe] hydrogenase from Desulfovibrio fructosovorans. Gene 94, 95-101.

Sambrook, J., Fritsch, E. F. \& Maniatis, T. (1989). Molecular Cloning, a Laboratory Manual, 2nd edn. Cold Spring Harbor, NY: Cold Spring Harbor Laboratory.

Sanger, F., Nicklen, S. \& Coulson, A. R. (1977). DNA sequencing with chain-terminating inhibitors. Proceedings of the National Academy of Sciences of the United States of America 74, 5463-5467.

SAWERS, R. C. \& BoXER, D. H. (1986). Purification and properties of membrane-bound hydrogenase isoenzyme 1 from anaerobically grown Escherichia coli K-12. European Journal of Biochemistry 156, 265-275.

Sawers, R. G., Ballantine, S. P. \& Boxer, D. H. (1985). Differential expression of hydrogenase isoenzymes in Escherichia coli $\mathrm{K}-12$ : evidence for a third isoenzyme. Journal of Bacteriology 164, 13241331.

Sayavedra-Soto, L. A., Powell, G. K., Evans, H. J. \& Morris, R. O. (1988). Nucleotide sequence of the genetic loci encoding subunits of Bradyrhizobium japonicum uptake hydrogenase. Proceedings of the National Academy of Sciences of the United States of America 85, 8395-8399.

SCHATZ, P. J. \& BECKWITH, J. (1990). Genetic analysis of protein export in Escherichia coli. Annual Review of Genetics 24, 215-248.

Towbin, H., STaEhelin, T. \& GoRDON, J. (1979). Electrophoretic transfer of proteins from polyacrylamide gels to nitrocellulose sheets: procedure and some applications. Proceedings of the National Academy of Sciences of the United States of America 76, 4350-4354.

Uffen, R. L., Colbeau, A., Richaud, P. \& Vignais, P. (1990). Cloning and sequencing the genes encoding the uptake-hydrogenase subunits of Rhodocyclus gelatinosus. Molecular and General Genetics 221, 4958 .

Van Dongen, W., Hagen, W., van den Berg, W. \& Veeger, C. (1988). Evidence for an unusual mechanism of membrane translocation of the periplasmic hydrogenase of Desulfovibrio vulgaris (Hildenborough), as derived from expression in Escherichia coli. FEMS Letters 50, 5-9.

VAN DER Westen, H. M., MAYhew, S. G. \& VeEger, C. (1978). Separation of hydrogenase from intact cells of Desulfovibrio vulgaris. FEBS Letters 86, 122-126.

Vlasuk, G. P., Inouye, S., Ito, H., Itakura, K. \& Inouye, M. (1983). Effects of the complete removal of basic amino acid residues from the signal peptide on secretion of lipoprotein in Escherichia coli. Journal of Biological Chemistry 258, 7141-7148.

VON HEIJNE, G. (1985). Signal sequences, the limits of variation. Journal of Molecular Biology 184, 99-105. 
Voordouw, G. (1990). Hydrogenase genes in Desulfovibrio. In Microbiology and Biochemistry of Strict Anaerobes Involved in Interspecies Hydrogen Transfer, pp. 37-51. Edited by J. P. Bélaich, M. Bruschi \& J. L. Garcia. New York: Plenum.

VOORDOUW, G. \& BRENNER, S. (1985). Nucleotide sequence of the gene encoding the hydrogenase from Desulfovibrio vulgaris (Hildenborough). European Journal of Biochemistry 148, 515-520.

Voordouw, G., HaGen, W. R., Krüse-Wolters, M., Van BerkelARTs, A. \& VeEger, C. (1987). Purification and characterization of Desulfovibrio vulgaris (Hildenborough) hydrogenase expressed in Escherichia coli. European Journal of Biochemistry 162, 31-36.

Voordouw, G., Menon, N. K., Legall, J., Choi, E. S., Peck, H. D. JR \& Przybyla, A. E. (1989a). Analysis and comparison of nucleotide sequences encoding the genes for $[\mathrm{NiFe}]$ and $[\mathrm{NiFeSe}]$ hydrogenases from Desulfovibrio gigas and Desulfovibrio baculatus. Journal of Bacteriology 171, 2894-2899.

Voordouw, G., Strang, J. D. \& Wilson, F. R. (1989b). Organization of the genes encoding [Fe] hydrogenase in Desulfovibrio vulgaris subsp. oxamicus Monticello. Journal of Bacteriology 171, 3881-3889.

VoOrdouw, G., Nivière, V., Ferris, F. G., Fedorak, P. M. \& WeSTLAKE, D. W. S. (1990). Distribution of hydrogenase genes in Desulfovibrio spp. and their use in identification of species from oil field environment. Applied and Environmental Microbiology 56, 37483754.

WATSON, M. E. E. (1984). Compilation of published signal sequences. Nucleic Acids Research 12, 5145-5164.

WoNG, S.-L. (1989). Development of an inducible and enhancible expression and secretion system in Bacillus subtilis. Gene 83, 215-223. 